\title{
Historein
}

Vol 14, No 2 (2014)

Historein 14/2 (2014)

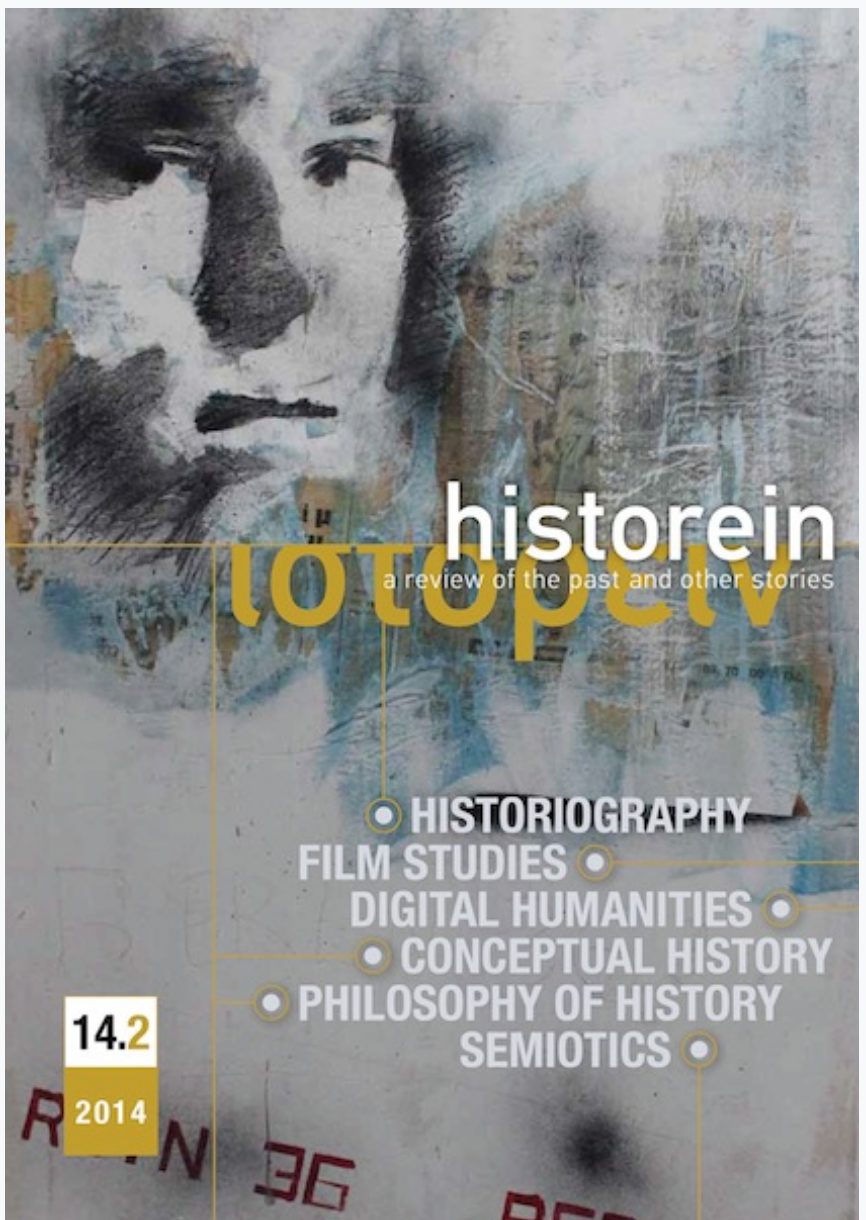

\section{Tartu-Moscow school of semiotics and history}

Taras Boyko

doi: $\underline{10.12681 / \text { historein.257 }}$

Copyright $\odot$ 2015, Taras Boyko

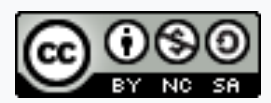

This work is licensed under a Creative Commons Attribution-NonCommercialShareAlike 4.0.

\section{To cite this article:}

Boyko, T. (2014). Tartu-Moscow school of semiotics and history. Historein, 14(2), 61-70. https://doi.org/10.12681/historein.257 
For a long period, Soviet (Russian) studies was perhaps one of the most popular research areas as regards regional studies in Western Europe and North America. Obviously there were many reasons for this popularity outside academia; however, more importantly, this interest in the Soviet Union (Russia) generally, and Soviet humanities in particular, created a rather distinct scholarly channel through which the ideas of many prominent Soviet humanities scholars could reach the "west". In a certain sense, it is even possible to say that in these circumstances the traditional flow of information (west as centre $\rightarrow$ everywhere else as "periphery") was reversed; ideas originating from the "peripheral" Soviet context made, or at least tried to make, an impact in the west. Clearly, the extent of this impact differed; in some cases it was quite essential and widely visible, ' in others it was limited only to the narrow frameworks of Slavistics and Russian literature departments. This article discusses a case which can be positioned in between these opposite poles, a case that, although it is not widely known and in some sense is even forgotten, at the peak of its popularity reached far beyond Slavistics/Russian literature departments. It is about Tartu-Moscow (semiotic) school ${ }^{2}$ and in particular the school's ideas related to history and historical writing.

The Tartu-Moscow school of semiotics was a somewhat unusual group of scholars with extremely wide and diverse research interests. It started in the early 1960s, primarily as a forum for academic discussions among friends and colleagues interested in semiotics, cybernetics, structuralism, the legacies of Russian formalism, and many other fascinating things bothering the minds of the au courant Soviet humanities scholars of the time. Already by the

\section{Tartu-Moscow} school of semiotics and history

\section{Taras Boyko}

University of Tartu 
mid-1960s, marked by a number of jointly organised conferences, summer schools, and even the establishment of a journal, ${ }^{3}$ the group had evolved into well-recognised and influential academic school. The majority of scholars who were (or at least considered to be) a part of the school, in terms of disciplinary identity, belonged either to a philology/literary studies field or linguistics. At the same time, philological and linguistic research agendas did not limit the scope of their academic interests. On the contrary, the naïve and very optimistic agenda of early semiotics presupposed the fearless transgression of established disciplinary boundaries. As a result, for many representatives of the school, overstepping these boundaries was a rather common practice and the school's attention to the problems associated with history, historiography, historical process, etc., are definitely one of the indicators of such interdisciplinary or even transdisciplinary tendencies.

However, when approaching the topic of the Tartu-Moscow school and history, it makes sense to differentiate two domains of history that were of interest to the school - one on the level of case studies and another on the level of theory/philosophy of history. The first concerns classical literary and cultural studies research when a scholar need to find some context for the topic he or she is studying (factual background, the biography of a writer or cultural figure, etc.). History and historical knowledge here become a prerequisite for any qualitative investigation of the problem discussed. For the most part, attention to history on this level concerns a relatively narrow and specific field determined by research limits, while sources are usually archival materials, manuscripts, letters, etc. Thus once the research is finished, the scholar (and readers) receive a more or less finalised set of information regarding those unresolved questions and "blank spots" that were at stake in the beginning. An important detail here is the fact that this information is verifiable; anybody interested can take a look at the sources used and trace the scholar's efforts in literary/cultural history. In the context of the school, such history on the case-study level was the basis for almost every literary or culturalogical analysis, so in the majority of works, be they pure literary history, history of culture, or something more exotic like studies of myth and religion, readers can find this casestudy level of interest in history.

History on the level of theory and philosophy of history is a more complicated domain. Here scholars usually work in a much broader field, sometimes even assuming some universal relevance. Obviously on this level, actual sources can be either numerous case studies and historical works or simply debates and comparisons with various ideas expressed by other historians, philosophers, etc. For instance, when trying to reflect on the essence and general nuances of historical writing, it will be difficult not to assume a certain universal relevance or avoid debates with some "classics" of historical theory. Unlike case-study level history, history on the level of theory and philosophy mainly ends up not with some finalised and verifiable outcomes, but with even more questions, uncertainties and at best only a few formulations of some unverifiable principles this or that scholar considers to be important and relevant. In some sense, this is a metalevel approach to history. It was definitely present in the context of the Tartu-Moscow school, but not as much when compared to case-study type of history.

The borders between these two domains aren't very strict. The levels can sometimes overlap or one can serve as a source for the other, but nevertheless it is important to point out that in 
the school's heritage there are different, traceable directions of interest in the topic of history/ historiography. One direction is a basis for literary and culturological research and is almost always present in the majority of works, while the other deals with a metalevel approach and appears primarily in the late 1970s, but especially blooms in the 1980s and early 1990s. For the purposes of the article, the second is more interesting. So the overall aim of this article is to present a case study in the history of ideas - to describe some of the ideas related to this metalevel domain and afterwards to briefly try and see how (and if) these ideas found their way into the western academic context.

\section{Yuri Lotman and history}

The leader of the school, Yuri Lotman, first clearly expressed interest in the nature of the historian's craft in a short piece in the late 1970s titled "K probleme raboty s nedostovernymi istochnikami" [On the problem of dealing with unreliable sources]. ${ }^{4}$ The starting point of the article is an indication of the fact that traditionally, according to Lotman, efforts of true scholarship were aimed at the detection of some apocryphal and pseudo-documental data, while the ultimate aim of this detection was to expulse "questionable" materials from a corpus of reliable sources in one or the other research area. Although Lotman certainly acknowledges all the pros of such a critical approach to sources, at the same time he expresses the idea that the notion of "credibility" (dostovernost') itself is rather relative. An absolute confidence in the reliability of some "credible" sources, or the categorical refusal to take into account doubtful/unreliable sources, can in a similar manner lead to some inappropriate conclusions and decisions. ${ }^{5}$ In Lotman's opinion, for a scholar equipped with suitable deciphering methods, even a deliberate forgery can become a source of very valuable information, and the contrary, the absence of such methods and techniques, can turn even the most authentic and credible document into a source of confusion. ${ }^{6}$

At first sight, these general observations of a Tartu professor might not seem that important, especially considering the point of view of contemporary scholarship. However in the Soviet historiographical context of the 1970s, which was dominated by Marxist-Leninist positivism, this idea that sources with low or even unknown credibility could, and eventually should, be reincorporated into the scholarly sphere of attention was quite novel. Unfortunately, this short article was never published in English, and the international "rediscovery" of the piece happened only in 2012, when it was raised at the annual Lotman Days conference held in Tallinn University.

Another example of Lotman's work discussing issues associated with historiographical matters is far better known (at least in Soviet and post-Soviet contexts) and is related to the publication, in the 15th volume of the school's journal, of the article by mathematicians Mikhail Postnikov and Anatoly Fomenko entitled "Novyye metodiki statisticheskogo analiza narrativno-tsifrovogo materiala drevney istorii" [New methods of statistical analysis of the narrative-numerical material of ancient history].' Lotman, as an editor of this volume of the journal, was not impressed by the article's rather controversial content. ${ }^{8}$ Thus, he included a short editorial note (so-called "objections") to accompany Postnikov and Fomenko's piece. Only few pages long, the note nevertheless contains a number of important provisions relevant for the understanding Lotman's conception of history and his opinion on the nature of historiographical practices. 
Postnikov and Fomenko's core idea was to analyse statistically numerous volumes of historical texts and eventually try to prove that at a certain point they were falsified. Lotman, in the editorial note, starts with the smallest unit of the proposed statistical analysis, the historical document $(\rightarrow$ historical source). For the Tartu professor, it is evident that any historical document can have and has a varied semiotic nature, which basically presupposes different "distortion factors" (koeffitsiyent iskazheniya) of the document, thus any approach to historical sources of such a varied semiotic nature also should be different, or at least the researcher should try to establish a "credibility" level for all the documents he or she intends to rely on. For instance, for Lotman it is clear that some texts (= sources of knowledge about the past) might have a very strong tendency towards mythologisation; these types of text simply hyperbolise and idealise events or persona they describe and in a certain sense are no longer about factual accuracy, but about the poetisation of description and use of various literary tools. And for obvious reasons, it can be misleading not to take into consideration such nuances ( $\rightarrow$ semiotic nature) of any particular historical document when trying to include it in a statistical analysis. Lotman especially stresses rituals of text composition, which are hardly taken into consideration, and suggests that any statistics-oriented account should be preceded by a semiotic analysis of each particular source. ${ }^{9}$ As a result, potential textual and narrative tools and devices accompanying the analysed source become a cornerstone element that should not be ignored.

Once again, neither Postnikov and Fomenko's article nor Lotman's editorial note were ever translated or published abroad, so for the most part Lotman's critique was simply turned into one of many arguments against Postnikov's and Fomenko's revisionist histories.

Towards the late 1980s, Lotman was even more interested in issues and problems associated with history and historical writing(s). This fruitful period was marked by his most encompassing and important contribution to the topic, Universe of the Mind: A Semiotic Theory of Culture, ${ }^{10}$ especially the third part of the book, "Cultural memory, history and semiotics" (which in the original Russian had the slightly different title of "Pamyat' Kul'tury. Istoriya i Semiotika").

The book was published in English in 1990 (although originally written in Russian in 1988-89) and from the outset it was envisaged as Lotman's first book intentionally written for a western audience. From the very first page of the third part, Lotman tackles one of the most crucial issues - the problem of the text. According to the Tartu professor, historians are condemned to deal with texts as a sort of intermediary agent between an event as it happened and a historian investigating it. Besides being an intermediary, text also occupies the place of the most biased element in the entire set of procedures associated with historical investigative practices, mainly because text is always "created by somebody and for some purpose, an event is presented in it in some encrypted way".11

According to Lotman, the outcome of such a situation for historians is that their starting point in any research narrows down to the need to deal with a potentially misrepresenting element, a need to decode this or that text and to some extent even create a fact while trying to extract an extratextual reality from the analysed text and an event from a story about the event. ${ }^{12}$ Lotman's stress here on concepts like code, encoder and decoder in connection to the historian and his source material became one of the essential pillars of his approach to the "problem of history" and historiog- 
raphy per se. In a way, such a terminological adaption from semiotics allows the Tartu scholar to juxtapose his semiotic understanding of history with a classical scheme of positivist text critique that is essentially rather judgmental in its essence $(\rightarrow$ the dominant technique of source analysis among professional historians, and especially historians working with the realia of Soviet "historical science").

Based on such an understanding of the situation in historiography, Lotman proposes to pay more attention to reconstructing the set of codes used by an author (chronicler, ancient historian, etc.) of the investigated source text, while at the same time correlating it with codes used here and now, meaning the codes of the historian or just an ordinary reader, as well as bearing in mind the difference between the synchronicity and asynchronicity of descriptions. Basically, the aim is to find out what was considered to be fact for the author of the analysed text and only afterwards to make any attempt to establish fact(s) "for yourself", which in the next step becomes a basis for outlining the range of potential interpretations of this fact. ${ }^{13}$

Further in the same chapter, Lotman turns to another crucial issue. He points out the inevitable structural unity brought about by the "narrativisation of events", a unity which organises material along temporal and causal coordinates. For Lotman it seems evident that rhetorical and ideological levels accompany a variety of genre-based narrative structures. Ideological, political, social, religious, philosophical and other codes should be taken into consideration as unavoidable elements in any narrative source. ${ }^{14}$

At first glance, the sort of ideas coming from Lotman do not appear to be something very revolutionary or somehow unexpected for historiography (and humanities in general) in the 1980s and early 1990s. However, we should not forget that Lotman was working and living in the Soviet Union, so there was shadow of the so-called Soviet factor present, meaning, for instance, the various limitations in terms of access to "foreign" books. It is not a secret that disciplinary history developed in the USSR in a very specific way, while western scholarly "revolutions" (such as the linguistic turn) hadn't reached the minds of the vast majority of Soviet historians.

It seems that Lotman, in the case of this work, autonomously goes further than traditional Soviet-type historism. On the one hand, he is still rather optimistic when speaking about history (for example, he constantly uses terms like "historical science"), ${ }^{15}$ but, at the same time, his (at times, quite extreme) texto-centrism and overwhelming attention to narrative devices, as well as the overall nature and structure of historical text, appear to come rather close to what in western historiography is usually referred as the "linguistic turn". Clearly, Lotman is not as radical as Hayden White, Frank Ankersmit and others, but in essence he grasps the core problem in and of history in a similar manner. It is again important to stress that this is all the more remarkable because it was done in the context of the rather isolated Soviet humanities, at a step ahead of Soviet professional historians.

Within the same "Cultural memory, history and semiotics" chapter, Lotman also articulates another notable idea concerning a slightly different dimension of the historian's job. Presumably sometime in early 1986, he read the Russian translation of the book by the famous physicist and 
chemist llya Prigogine, Order out of Chaos. ${ }^{16}$ Impressed by his ideas regarding complex systems, dissipative structures and dynamic processes, Lotman decided to adopt some of these ideas into the realm of historical processes as well as studies of history in general. As an outcome of such cooperation, Lotman proposed a basic assumption that a historical event should be seen as the result of one of multiple alternatives, meaning that at certain point (the "point of bifurcation") the same circumstances in history might not have unequivocal consequences. In Lotman's view, "realised" historical paths appear surrounded by clusters of "unrealised" possibilities, while the alleged determinism of the historical process is nothing other than a product of retrospective approach. The historian as a rückwärts gekehrter Prophet ${ }^{17}$ eliminates uncertainty, but at the same time this elimination also bridges the position of a historian as an "interpreter" with the position of an ordinary interpreter of literary work (a literary critic, for example). It seems that what Lotman tries to do here is to highlight these randomness-determinism issues in history and historiography, meaning that all the games with history place the historian before an inevitable double distortion; on the one hand, the historian faces all the pitfalls of narrative structures, while on the other the unavoidable retrospective approach to the past (present $\rightarrow$ past) in essence neglects conscious individual choices in history, which are very important to Lotman.

Unlike the previous examples of Lotman's works, Universe of the Mind received a decent amount of scholarly attention in the west, possibly on the grounds that Lotman was that important voice from the collapsing USSR, or because the foreword to the book was written by the highly popular Umberto Eco. Either way, Lotmanian ideas were heard and, from time to time, even cited.

\section{Boris Uspensky and history}

On numerous occasions, Lotman noted that his ideas about history and historiography developed greatly as a result of extensive discussions with another prominent school member, Boris Uspensky. Uspensky, besides being a close friend of Yuri Mikhailovich for many years, was also one of Lotman's most frequent co-authors. While in terms of the number of independent articles dedicated to the topic of history, both on the case-study level and theory-aspect level, the Moscow scholar is probably even ahead of his Tartu colleague.

In 1976 Uspensky published an article under the somewhat provocative title "Historia sub specie semioticae". It is very short, but nevertheless very concrete in terms of the ideas expressed. In it, he says:

From a semiotic perspective, the historical process can be conceived of as a communication process in which the new information that is constantly being received conditions a reciprocal reaction on the part of the societal addressee or social group. Some "language", understood in a broad semiotic rather than a narrow linguistic sense, determines perception of both real and potentially possible facts in the corresponding historical-cultural context. In this way, meaning is attributed to events: a text of events is read by a social group. We can say, then, that in its rudimentary phase, the historical process is a process of generating new "sentences" in some "language" and of having them read by a societal addressee or social group. ${ }^{18}$ 
As a follow up to this crucial paragraph, Uspensky tries to stress the essential role of miscommunication or "conflict" of interpretation that manifests itself in cases where two or more different languages describe one and the same reality, or when the sender and receiver of the message use different languages while having similar external means of expression. "Historia sub specie semioticae" was almost immediately recognised in the west, so translation into English, ${ }^{19}$ Spanish, ${ }^{20}$ French ${ }^{21}$ and somewhat later into Italian ${ }^{22}$ followed.

Another of Uspensky's milestone works investigating history on the level of the theoretical aspect appeared more than a dozen years later and was titled "Istoriya i Semiotika (Vospriyatiye vremeni kak semioticheskaya problema)" [History and semiotics: perception of time as a semiotic problem]. ${ }^{23}$ In this article, he continues to follow his central idea about the historical process being recognised as a communication with a certain "language" serving as code. However, this time he also acknowledges the possibilities of other models and interpretations of history; he states that various interpretations do not deny but, on the contrary, complement each other and in a way reflect the general complexity of the historical process. The cultural-semiotic approach that he proposed (which to some extent was shared by many members of the school), however, presumes attention to an "internal" point of view of the participants in the historical process. So, in this case, what is significant and meaningful is only what is recognised as significant and meaningful by the participants in the historical process. The idea behind such an approach is to reconstruct those subjective motives that developed into impulses for action. The behaviour of society (socium) reacting to an event also can be interpreted with the help of the same categories, because society (socium) can be represented as a collective individual.

Uspensky also expands on the notion of "certain "language"' (nekotoryy "yazyk") used for "reading" history. For him, on the one hand this "language" brings together and unites particular societies, causing a more or less similar reaction of its members to unfolding events, thus creating a "collective individual". However, on the other hand, this "language" in some sense organises incoming information, thus resulting in a selection of some "important" facts and the establishment of cause-effect relations, while anything that cannot be described using this "language" is simply dismissed or goes unnoticed.

Uspensky dedicates a key part of his article to supporting the argument that "History is semiotic in its nature ... it involves certain semiotisation of reality - transformation of non-sign into a sign and non-history into a history." The unfolding of events in time implies a "language" factor ( $\rightarrow$ semiotics of language), while the perception of history a factor of signs ( $\rightarrow$ semiotics of sign). Together, this combination, along with conditions of temporal sequence and cause-and-effect relations, ensures the semiosis of history.

Slightly surprisingly, Italian historian Luisa Passerini picked up Uspensky's point about semiotisation. ${ }^{24}$ She basically takes his viewpoint on history as a communicative process and, in an article published in 1999, bridges it with a contemporary situation in western historiography. In her opinion, the semiotisation of history stands in opposition to the prevailing structuralist definition of history, where history is reduced to nothing more than "a pulverisation of infinitesimal events, 
to which only the subjective choices of the historian intervened to give some sense". ${ }^{25}$ In contrast, Passerini suggests falling in with Uspensky in considering the plurality and discontinuity of history conceived as a communicative process.

Such an interpretation and adaption of Uspensky's ideas is rather engaging, since on the one hand both Uspensky and Lotman in the late 1980s and early 90s were heavily influenced by nouvelle histoire, ${ }^{26}$ which was fashionable at the time in the Soviet Union; however, at the same time their ideas regarding the semiotics of history, at least according to Passerini, can be viewed also as an essential and rather novel step that historians now should take in order to assume their role in the cultural scene of the present. ${ }^{27}$

\section{Some conclusions}

The Tartu-Moscow school left an important trace in Soviet (and, to some extent, not only Soviet) humanities. Although the topic of history and historiography was on the margins of the school's research agendas (at least in terms of the overall volume of works), a number of scholars from Tartu and Moscow, while being relatively free from the academic conservatism and some of the limitations of Soviet historiography, still voiced rather novel and interesting ideas regarding history and the historian's craft. By doing so, they, in a way, catalysed new discussions and highlighted previously disregarded areas. Thus, at the end we have a whole layer of works that not only tries to introduce a new approach to history and matters historical (especially important in the context of the almost totally isolated Soviet historical science), but also, optimistically, proposes some sort of solution to various problems that usually tend to be left out of the scope of attention of professional historians. It is hard to disagree with the fact that the 1970s and 80s were an interesting time for historical studies, as well as for the humanities overall, and the "textocentrism" of scholars like Lotman played a notable role in a general history of ideas during this period. In narrower context, and because of the certain objective reasons inside the Soviet humanities mentioned earlier, Lotman also happened to be in the avant-garde of many "new" ideas.

Lotman, with his "Cultural memory, history and semiotics" (as well as the whole book Universe of the Mind), was among the first in Soviet historiography to emphasise the necessity of paying particular attention to various narrative devices and overall structure of historical texts, to acknowledge the historian's role, and to question the problem of alternatives in history along with alterative histories. The latter also seems especially important, since the collapse of Soviet Union and Soviet historiographical traditions, which happened shortly after the work was written, paved the way for a parade of "alternative histories" throughout the former USSR, while historical revisionism "bloomed" as never before, thus serving as a posteriori case-study illustration of Lotman's ideas.

However, attention to all these theoretical and partly even philosophical questions in a way never paid off for Yuri Lotman. Among Soviet historians, his ideas were barely accepted and almost never widely cited simply because they were too radical for the Soviet historiographical field. And for western readers, who were supposed to be the primary audience of Universe of the Mind, Lotmanian ideas regarding history were already obsolete within a decade or so. 


\section{NOTES}

1 Perhaps the best-known example here is the "introduction" to the ideas of Mikhail Bakhtin.

2 Sometimes also referred to as "Soviet school of semiotics" or simply "Soviet semiotics".

3 Between 1964 and 1992, it was called Trudy po znakovym sistemam (Sign System Studies) and published in Russian. In the late 1990s, the journal reemerged as Sign System Studies and is published in English.

4 Yuri Lotman, "K probleme raboty s nedostovernymi istochnikami" [On the problem of dealing with unreliable sources], in Vremennik Pushkinskoy komissii [Annals of the Pushkin Commission] 13 (1975): 93-98.

$5 \quad$ Ibid., 93.

$6 \quad$ Ibid., 94.

$7 \quad$ Mikhail Postnikov and Anatoly Fomenko, "Novyye metodiki statisticheskogo analiza narrativno-tsifrovogo materiala drevney istorii," Trudy po znakovym sistemam [Sign System Studies] 15 (1982): 2443. It may also make sense to mention that Fomenko later became one of the main revisionist historians (history of "new chronology") in Russia, eventually turning into constant target of critique for many professional historians.

8 For example, on 28 March 1980 Lotman wrote to Uspensky: “Stat'ja Postnikova — bred! No pechatat' budem" (Postnikov's article - nonsense! But we will print it).

9 See Lotman's editorial note on Postnikov and Fomenko's article in Trudy po znakovym sistemam [Sign System Studies] 15 (1982): 44-45.

10 Yuri Lotman, Universe of the Mind: A Semiotic Theory of Culture. trans. Ann Shukman, intro. Umberto Eco (London: IB Tauris, 1990).

11 Here and below, all references will be according to the original Russian version published as Vnytri Mysliashih Mirov. Chelovek-tekst-semiosfera-istoria [Inside thinking worlds: man-text-semioshperehistory] (Moscow: Jazyki Russkoj Kul'tury, 1996), 301-302.

12 Ibid.

13 Ibid., 302-303.

14 Ibid., 310.

15 Ibid., 301 (although it should be taken into consideration that the Russian term "nauka" used by Lotman does not entirely correspond to the English term "science", so translating "nauka" as "science" is somewhat a stretch).

16 Ilya Prigogine and Isabelle Stengers, Order out of Chaos: Man's new Dialogue with Nature (London: Flamingo, 1984).

17 Friedrich Schlegel's well-known phrase about the historian being a prophet facing backwards.

18 Boris Uspensky, "Historia sub specie semioticae," in Kul'turnoye naslediye Drevney Rusi. Istoki, stanovleniye, traditsii [Cultural heritage of ancient Rus': origins. formation. traditions], ed. Vasily Bazanov (Moscow: Nauka, 1976), 286.

19 Boris Uspensky, "Historia sub specie semioticae," in Soviet Semiotics, ed. Daniel Lucid (Baltimore: Johns Hopkins University Press, 1977), 107-115. 
20 Boris Uspensky, "Historia sub specie semioticae," in Lotman y Escuela de Tartu. Semiótica de la cultura, intro. and ed. Jorge Lozano (Madrid: Cátedra, 1979), 209-218.

21 Boris Uspensky, "Historia sub specie semioticae," in Travaux sur le Systèmes de Signes (Brussels: Éditions Complexe, 1976), 141-152.

22 Boris Uspensky, Storia e semiotica (Milan: Bompiani, 1988), 1-8.

23 In reality, it is two articles in two parts with the same title, "Istoriya i Semiotika (Vospriyatiye vremeni kak semioticheskaya problema) [History and semiotics: time perception as a semiotic problem], that appeared in volumes $22(1988,66-84)$ and $23(1989,18-38)$ of Trudy po znakovym sistemam [Sign System Studies].

24 Luisa Passerini, "History and Semiotics," in Historein 1 (1999): 13-20.

25 Ibid., 14.

26 In Universe of the Mind, Lotman on multiple occasions mentions the example of the Annales school and even debates with Marc Bloch, while Uspensky in the articles mentioned doesn't directly refer to the French historiographical school, but readers can easily feel that he definitely relies on some ideas associated with the Annales or at least takes into consideration trends coming from it.

27 Passerini, "History and Semiotics", 19. 